
\title{
$\begin{array}{ll}\text { Research Square } & \begin{array}{l}\text { Preprints are preliminary reports that have not undergone peer review. } \\ \text { They should not be considered conclusive, used to inform clinical practice, } \\ \text { or referenced by the media as validated information. }\end{array}\end{array}$
}

\section{Clinical presentation, pregnancy complications and maternal outcomes of SARS-CoV-2 infection in pregnant women during the third wave of COVID-19 in Mumbai, India}

Niraj Mahajan ( $\nabla$ nirajdr@hotmail.com )

BYL Nair Charitable Hospital and TN Medical College, Mumbai https://orcid.org/0000-0003-4030-460X

Shweta Kesarwani

BYL Nair Charitable Hospital and TN Medical College, Mumbai

Chetna Salunke

BYL Nair Charitable Hospital and TN Medical College, Mumbai

\section{Padmaja Kumbhar}

BYL Nair Charitable Hospital and TN Medical College, Mumbai

\section{Piyusha Yenkure}

BYL Nair Charitable Hospital and TN Medical College, Mumbai

\section{Juvairiya Shaikh}

BYL Nair Charitable Hospital and TN Medical College, Mumbai

\section{Shrutika Shikhare}

BYL Nair Charitable Hospital and TN Medical College, Mumbai

\section{Smita Mahale}

National Institute for Research in Reproductive Health

\section{Geetanjali Sachdeva}

ICMR-National Institute for Research in Reproductive and Child Health, Mumbai, India, 400012

\section{Rahul Gajbhiye}

National Institute for Research in Reproductive Health

\section{Brief Communication}

Keywords:

Posted Date: January 26th, 2022

DOI: https://doi.org/10.21203/rs.3.rs-1293921/v1

License: (c) (i) This work is licensed under a Creative Commons Attribution 4.0 International License. Read Full License 


\section{Abstract}

Importance: Following the outbreak of SARS-CoV-2 infection, it is unclear whether there is any difference in clinical presentation, disease severity, pregnancy complications, and maternal outcomes in pregnant and postpartum women during the third wave of COVID-19 as compared to the earlier two waves of COVID-19.

Objective: To assess the clinical presentation, disease severity, pregnancy complications, and maternal outcomes in women affected with COVID-19 during the third wave in India and compare these parameters with the first wave and second wave of COVID-19.

Design: Retrospective observational cohort study

Setting: Tertiary care, dedicated COVID-19 hospital catering to Mumbai Metropolitan Region, India

Participants: A total of 2,028 pregnant and postpartum women were admitted during three-wave periods: first wave $-1^{\text {st }}$ April 2020 to $31^{\text {st }}$ January 2021, second wave $-1^{\text {st }}$ February 2021 to $10^{\text {th }}$ December 2021; and third wave $-18^{\text {th }}$ December 2021 to $19^{\text {th }}$ January 2022.

Exposures: SARS-CoV-2 infection in pregnant and post-partum women confirmed by laboratory confirmation of COVID-19

Main Outcomes and Measures: The primary outcome measures were disease severity, pregnancy complications, and maternal mortality during the third wave compared to the first and second waves of COVID-19.

Results: A total of 2028 pregnant and postpartum women with COVID-19 diagnosis were enrolled during the first, second, and third waves of COVID-19. The hospitalization rate of pregnant and post-partum women with COVID-19 during the first four weeks of the third wave was higher than the earlier two waves as 288 women got admitted within 33 days. The number of SARS-CoV-2 infected pregnant and post-partum women with symptoms of COVID-19 were five times higher during the third wave as compared to the first wave $(\mathrm{OR}=5.1,95 \% \mathrm{Cl}, 3.8-6.7, \mathrm{p}<.001)$. On the contrary, there was a significantly lower proportion of pregnant and postpartum women with moderate to severe COVID-19 during the third wave $(0.3 \%, 1 / 288)$ as compared to those during the first wave $(2.4 \%, 27 / 1143, p<.001)$ and second wave $(14.4 \%, 86 / 597)$ [p<.001]. The ICU/HDU admissions during the third wave were significantly lower $(2.4 \%, 7 / 288)$ than those during the second wave $(14.7 \%, 88 / 597)$ [OR $=0.1,95 \% \mathrm{Cl}, 0.1-0.3, \mathrm{p}<.001]$ but similar to the first wave $(2.4 \%, 27 / 1143)$. No maternal deaths were reported during the third wave till 19th January 2022. Eclampsia was observed four times higher during the third wave as compared to the second wave $(\mathrm{OR}=4.1,95 \% \mathrm{Cl}, 0.8-22.6, \mathrm{p}=.19)$ and first wave $(\mathrm{OR}=4.4,95 \% \mathrm{Cl}, 0.9-12.7, \mathrm{p}=.15)$.

Conclusions and Relevance: Decreased severity of COVID-19 and reduced maternal mortality and morbidity were reported in the third wave as compared to the first wave and second wave of COVID-19 in the Mumbai Metropolitan Region, India.

\section{Trial Registration:}

The study is registered with the Clinical Trial Registry of India (Registration no: CTRI/2020/05/025423).

\section{Key Points}

Question: What is the clinical presentation, disease severity, pregnancy complications, and maternal outcomes in women affected with COVID-19 during the third wave as compared to those during the first and second waves of COVID-19?

Findings: In this retrospective cohort study, different transmission curves and epidemiological profiles were observed in pregnant and postpartum women with COVID-19 during the third wave compared to the first and second waves in the Mumbai Metropolitan Region, India. A higher proportion of symptomatic cases, lower severity, and lower case fatality were reported amongst the pregnant and postpartum women with COVID-19 in India. 
Meaning: There was decreased severity of disease and reduced maternal mortality and morbidity in the third wave as compared to the first wave and second wave of COVID-19 in the Mumbai Metropolitan Region, India.

\section{Introduction}

A new SARS-CoV-2 variant B.1.1.529 (Omicron) was reported from South Africa on 24 November 2021 and was declared as a variant of concern (VoC) by WHO on 26 November $2021^{1}$. The dramatic rise in the number of COVID-19 cases caused by highly transmissible Omicron in South Africa, the United Kingdom, and the USA was followed by a sudden rise in COVID-19 cases reported in India from mid-December 2021 onwards, indicating the beginning of the third wave of the COVID-19 pandemic in India. As per the INSACOG report of 3rd January 2022, the Omicron is in the phase of community transmission in India, and the omicron variant is dominant in Mumbai as well as other metropolitan regions ${ }^{2}$. As of January 20, 2022, there were 35.8 million cases with 0.5 million deaths attributed to COVID-19 in India ${ }^{3}$. Pregnant and postpartum women infected with SARS-CoV-2 were reported to have adverse outcomes during the first and second waves of COVID-19 in India. ${ }^{4,5}$ Moreover, the second wave of COVID-19 was associated with a higher frequency of severe COVID-19 disease, intensive care unit (ICU) or high dependency unit admission (HDU), and high maternal mortality as compared to the first wave in Mumbai Metropolitan Region, India. ${ }^{5}$ To date, no information is available on the impact of the third wave of COVID19 on pregnant and post-partum women in India. Here, we present the data on clinical presentation, disease severity, pregnancy complications, and maternal outcomes in women affected with COVID-19 during the third wave in India and the comparative analysis with the first and second waves of COVID-19.

\section{Methods}

We conducted a retrospective observational cohort study of pregnant and postpartum women with laboratory-confirmed SARS-CoV-2, admitted at BYL Nair Charitable Hospital (NH), Mumbai, India. NH is one of the network hospitals of the PregCovid registry and the only dedicated COVID-19 tertiary care hospital, during most of the duration of all three waves catering to the most densely populated Mumbai Metropolitan Region comprising of 26 million population. ${ }^{6}$ The data were analyzed for the three-wave periods: first wave - 1st April 2020 to 31st January 2021, second wave - 1st February 2021 to 10th December 2021; and third wave - 18th December 2021 to 19th January 2022 [Table 1]. The hospital admission policy 6 was uniform during all three waves of the COVID-19 pandemic period. The data were captured as per the standardized data collection methods of the PregCovid registry. ${ }^{7}$ A total of 2028 pregnant and post-partum women with COVID-19 were admitted during the first, second, and third wave of COVID-19 at NH. 
Table 1

Comparative analysis of clinical presentation, disease severity, and outcomes of SARS-CoV-2 infection in pregnant women during $1 \mathrm{st}, 2^{\text {nd, }}$ and 3 rd waves of COVID-19 in Mumbai, India

\begin{tabular}{|c|c|c|c|c|c|c|c|c|c|}
\hline \multirow[t]{2}{*}{ Parameter } & \multirow{2}{*}{$\begin{array}{l}\text { 1st wave } \\
\text { (April 2, } \\
\text { 2020- } \\
\text { January } \\
\text { 31, 2021) }\end{array}$} & \multirow{2}{*}{$\begin{array}{l}\text { 2nd wave } \\
\text { (February } \\
1- \\
\text { December } \\
\text { 10, 2021) }\end{array}$} & \multirow{2}{*}{$\begin{array}{l}\text { 3rd wave } \\
\text { (December } \\
18,2021- \\
\text { January } \\
19,2022)\end{array}$} & \multicolumn{2}{|c|}{$\begin{array}{l}\text { 2nd wave vs 1st } \\
\text { wave }\end{array}$} & \multicolumn{2}{|c|}{$\begin{array}{l}\text { 3rd wave vs } \\
\text { 1st wave }\end{array}$} & \multicolumn{2}{|c|}{$\begin{array}{l}\text { 3rd wave } \\
\text { vs 2nd } \\
\text { wave }\end{array}$} \\
\hline & & & & $\begin{array}{l}\text { OR } \\
\text { (95\% } \\
\text { Cl) }\end{array}$ & $\begin{array}{l}P \\
\text { value }\end{array}$ & $\begin{array}{l}\text { OR } \\
\text { (95\% } \\
\text { Cl) }\end{array}$ & $\begin{array}{l}P \\
\text { value }\end{array}$ & $\begin{array}{l}\text { OR } \\
\text { (95\% } \\
\text { Cl) }\end{array}$ & $\begin{array}{l}P \\
\text { value }\end{array}$ \\
\hline
\end{tabular}

\section{Demographic} characteristics

Total no. of pregnant $\quad 1143 \quad 597 \quad 288$ and post-partum women managed at $\mathrm{NH}$

Median age in years (IQR) 27 (2428 (25$26(24-29)$ .07 .02 .001

\section{Clinical presentation}

$\begin{array}{llll}\text { Asymptomatic }(\mathrm{n}, \%) & 981 & 363 & 157(54.5) \\ & (85.8) & (60.8) & \end{array}$

\begin{tabular}{|c|c|c|c|c|c|c|c|c|}
\hline Symptomatic (n, \%) & $\begin{array}{l}162 \\
(14.2)\end{array}$ & $\begin{array}{l}234 \\
(39.2)\end{array}$ & $131(45.5)$ & $\begin{array}{l}3.9 \\
(3.1- \\
4.9)\end{array}$ & $<.001$ & $\begin{array}{l}5.1 \\
\text { (3.8- } \\
6.7)\end{array}$ & $<.001$ & $\begin{array}{l}1.3 \\
(1.0- \\
1.7)\end{array}$ \\
\hline
\end{tabular}

Severity of COVID-19

$\begin{array}{llll}\cdot \text { Mild } & 135 & 148(25) & 130(45.1) \\ & (11.8) & & \end{array}$

\begin{tabular}{|c|c|c|c|c|c|c|c|c|}
\hline - Moderate and Severe & $27(2.4)$ & $86(14.4)$ & $1(0.3)$ & $\begin{array}{l}2.9 \\
(1.8- \\
4.8)\end{array}$ & $<.001$ & $\begin{array}{l}0.04 \\
(0.01- \\
0.29)\end{array}$ & $<.001$ & $\begin{array}{l}0.01 \\
(0.0- \\
0.1)\end{array}$ \\
\hline
\end{tabular}

\section{Comorbidities}

\begin{tabular}{|c|c|c|c|c|c|c|c|c|c|}
\hline Anemia $(\mathrm{Hb}<11 \mathrm{~g} / \mathrm{dL})$ & $\begin{array}{l}484 / 1042 \\
(46.4)\end{array}$ & $\begin{array}{l}356 / 597 \\
(59.6)\end{array}$ & $\begin{array}{l}132 / 288 \\
(45.8)\end{array}$ & $\begin{array}{l}1.7 \\
(1.4- \\
2.1)\end{array}$ & $<.001$ & $\begin{array}{l}1.0 \\
(0.8- \\
1.3)\end{array}$ & .85 & $\begin{array}{l}0.6 \\
(0.4- \\
0.8)\end{array}$ & $<.001$ \\
\hline Chronic Hypertension & $14(1.2)$ & $5(0.8)$ & $2(0.7)$ & $\begin{array}{l}0.7 \\
(0.2- \\
1.9)\end{array}$ & .46 & $\begin{array}{l}0.6 \\
(0.1- \\
2.5)\end{array}$ & .69 & $\begin{array}{l}0.8 \\
(0.2- \\
4.3)\end{array}$ & $>.99$ \\
\hline Diabetes Mellitus & $8(0.7)$ & $7(1.2)$ & $1(0.3)$ & $\begin{array}{l}1.7 \\
(0.6- \\
1.7)\end{array}$ & .31 & $\begin{array}{l}0.5 \\
(0.1- \\
4.0)\end{array}$ & .86 & $\begin{array}{l}0.3 \\
(0.0- \\
2.4)\end{array}$ & .41 \\
\hline Bronchial Asthma & $8(0.7)$ & $4(0.7)$ & $2(0.7)$ & $\begin{array}{l}1.0 \\
(0.3- \\
3.2)\end{array}$ & $>.99$ & $\begin{array}{l}1.0 \\
(0.2- \\
4.7)\end{array}$ & $>.99$ & $\begin{array}{l}1.0 \\
(0.2- \\
5.7)\end{array}$ & $>.99$ \\
\hline
\end{tabular}

* Hemorrhagic complications include antepartum hemorrhage + postpartum hemorrhage + hemoperitoneum

${ }^{a}$ Cardiac Disease includes rheumatic heart disease + congenital heart disease + peripartum cardiomyopathy

${ }^{b}$ Out of 7 ICU/HDU admissions during the third wave one was moderate COVID-19, other six were not related to COVID19 severity; two were pulmonary edema secondary to severe preeclampsia/eclampsia (one had stillbirth and was on NIV, other needed invasive ventilation), one was eclampsia with posterior reversible encephalopathy syndrome (PRES), one was severe rheumatic mitral stenosis and two were ruptured ectopic (one with massive blood loss needing ionotropic support and other had transfusion reaction). 


\begin{tabular}{|c|c|c|c|c|c|c|c|c|c|}
\hline \multirow[t]{2}{*}{ Parameter } & \multirow{2}{*}{$\begin{array}{l}\text { 1st wave } \\
\text { (April 2, } \\
2020- \\
\text { January } \\
31,2021 \text { ) }\end{array}$} & \multirow{2}{*}{$\begin{array}{l}\text { 2nd wave } \\
\text { (February } \\
1- \\
\text { December } \\
\text { 10, 2021) }\end{array}$} & \multirow{2}{*}{$\begin{array}{l}\text { 3rd wave } \\
\text { (December } \\
18,2021- \\
\text { January } \\
19,2022)\end{array}$} & \multicolumn{2}{|c|}{$\begin{array}{l}\text { 2nd wave vs 1st } \\
\text { wave }\end{array}$} & \multicolumn{2}{|c|}{$\begin{array}{l}\text { 3rd wave vs } \\
\text { 1st wave }\end{array}$} & \multicolumn{2}{|c|}{$\begin{array}{l}\text { 3rd wave } \\
\text { vs } 2 \text { nd } \\
\text { wave }\end{array}$} \\
\hline & & & & $\begin{array}{l}\text { OR } \\
(95 \% \\
\text { Cl) }\end{array}$ & $\begin{array}{l}P \\
\text { value }\end{array}$ & $\begin{array}{l}\text { OR } \\
(95 \% \\
\text { Cl) }\end{array}$ & $\begin{array}{l}P \\
\text { value }\end{array}$ & $\begin{array}{l}\text { OR } \\
(95 \% \\
\text { Cl) }\end{array}$ & $\begin{array}{l}P \\
\text { value }\end{array}$ \\
\hline Cardiac Disease $^{a}$ & $8(0.7)$ & $7(1.2)$ & $4(1.4)$ & $\begin{array}{l}1.7 \\
(0.6- \\
4.7)\end{array}$ & .31 & $\begin{array}{l}2.0 \\
(0.6- \\
6.7)\end{array}$ & .42 & $\begin{array}{l}1.2 \\
(0.34- \\
4.1)\end{array}$ & $>.99$ \\
\hline Hypothyroidism & $77(6.7)$ & $48(8.0)$ & $14(4.9)$ & $\begin{array}{l}1.2 \\
(0.8- \\
1.8)\end{array}$ & .32 & $\begin{array}{l}0.7 \\
(0.4- \\
1.3)\end{array}$ & .24 & $\begin{array}{l}0.6 \\
(0.3- \\
1.1)\end{array}$ & .08 \\
\hline \multicolumn{10}{|l|}{$\begin{array}{l}\text { Obstetrics } \\
\text { characteristics }\end{array}$} \\
\hline $\begin{array}{l}\text { Gestational age at } \\
\text { COVID-19 diagnosis } \\
\text { (wks.) Median (IQR) }\end{array}$ & $\begin{array}{l}38(37- \\
39)\end{array}$ & $\begin{array}{l}38(31- \\
39)\end{array}$ & 38 (34-39) & - & $<.001$ & - & $<.001$ & - & .20 \\
\hline Total Delivery (n, \%) & 807 & 381 & 196 & & & & & & \\
\hline Cesarean birth & $\begin{array}{l}324 \\
(40.1)\end{array}$ & $\begin{array}{l}145 \\
(38.1)\end{array}$ & $60(30.6)$ & $\begin{array}{l}0.9 \\
(0.7- \\
1.2)\end{array}$ & .49 & $\begin{array}{l}0.7 \\
(0.5- \\
0.9)\end{array}$ & .01 & $\begin{array}{l}0.7 \\
(0.5- \\
1.0)\end{array}$ & .08 \\
\hline Total Births & 822 & 393 & 197 & & & & & & \\
\hline $\begin{array}{l}\text { Spontaneous Preterm } \\
\text { birth rate (per } 1000 \\
\text { births) }\end{array}$ & $67(81.5)$ & $\begin{array}{l}42 \\
(106.9)\end{array}$ & $12(60.9)$ & $\begin{array}{l}1.4 \\
(0.9- \\
2.0)\end{array}$ & .15 & $\begin{array}{l}0.7 \\
(0.4- \\
1.4)\end{array}$ & .33 & $\begin{array}{l}0.5 \\
(0.3- \\
1.1)\end{array}$ & .07 \\
\hline $\begin{array}{l}\text { Spontaneous abortions } \\
\text { rate (per } 1000 \text { births) }\end{array}$ & $22(26.8)$ & $30(76.3)$ & $9(45.7)$ & $\begin{array}{l}3.0 \\
(1.7- \\
5.3)\end{array}$ & $<.001$ & $\begin{array}{l}1.7 \\
(0.8- \\
3.8)\end{array}$ & .17 & $\begin{array}{l}0.6 \\
(0.3- \\
1.3)\end{array}$ & .16 \\
\hline $\begin{array}{l}\text { Ectopic pregnancy rate } \\
\text { (per } 1000 \text { births) }\end{array}$ & $3(3.6)$ & $4(10.2)$ & $2(10.2)$ & $\begin{array}{l}2.8 \\
(0.6- \\
12.6)\end{array}$ & .22 & $\begin{array}{l}2.8 \\
(0.5- \\
16.9)\end{array}$ & .50 & $\begin{array}{l}1.0 \\
(0.2- \\
5.5)\end{array}$ & $>.99$ \\
\hline $\begin{array}{l}\text { Stillbirth rate (per } 1000 \\
\text { births) }\end{array}$ & $12(14.6)$ & $13(33.1)$ & $2(10.2)$ & $\begin{array}{l}2.3 \\
(1.0- \\
5.1)\end{array}$ & .03 & $\begin{array}{l}0.7 \\
(0.2- \\
3.1)\end{array}$ & .94 & $\begin{array}{l}0.3 \\
(0.1- \\
1.3)\end{array}$ & .10 \\
\hline $\begin{array}{l}\text { Pregnancy } \\
\text { complications; } \\
\text { n=Gestational Age }>20 \\
\text { weeks }\end{array}$ & 1103 & 535 & 263 & & & & & & \\
\hline $\begin{array}{l}\text { Gestational Diabetes } \\
\text { Mellitus }\end{array}$ & $26(2.4)$ & $28(5.2)$ & $5(1.9)$ & $\begin{array}{l}2.3 \\
(1.3- \\
3.9)\end{array}$ & .001 & $\begin{array}{l}0.8 \\
(0.3- \\
2.1)\end{array}$ & .61 & $\begin{array}{l}0.4 \\
(0.1- \\
0.9)\end{array}$ & .03 \\
\hline
\end{tabular}

\footnotetext{
* Hemorrhagic complications include antepartum hemorrhage + postpartum hemorrhage + hemoperitoneum

${ }^{a}$ Cardiac Disease includes rheumatic heart disease + congenital heart disease + peripartum cardiomyopathy

${ }^{b}$ Out of 7 ICU/HDU admissions during the third wave one was moderate COVID-19, other six were not related to COVID19 severity; two were pulmonary edema secondary to severe preeclampsia/eclampsia (one had stillbirth and was on NIV, other needed invasive ventilation), one was eclampsia with posterior reversible encephalopathy syndrome (PRES), one was severe rheumatic mitral stenosis and two were ruptured ectopic (one with massive blood loss needing ionotropic support and other had transfusion reaction).
} 


\begin{tabular}{|c|c|c|c|c|c|c|c|c|c|}
\hline \multirow[t]{2}{*}{ Parameter } & \multirow{2}{*}{$\begin{array}{l}\text { 1st wave } \\
\text { (April 2, } \\
2020- \\
\text { January } \\
31,2021 \text { ) }\end{array}$} & \multirow{2}{*}{$\begin{array}{l}\text { 2nd wave } \\
\text { (February } \\
1- \\
\text { December } \\
10,2021 \text { ) }\end{array}$} & \multirow{2}{*}{$\begin{array}{l}\text { 3rd wave } \\
\text { (December } \\
\text { 18, 2021- } \\
\text { January } \\
19,2022 \text { ) }\end{array}$} & \multicolumn{2}{|c|}{$\begin{array}{l}\text { 2nd wave vs 1st } \\
\text { wave }\end{array}$} & \multicolumn{2}{|c|}{$\begin{array}{l}\text { 3rd wave vs } \\
\text { 1st wave }\end{array}$} & \multicolumn{2}{|c|}{$\begin{array}{l}\text { 3rd wave } \\
\text { vs } 2 \text { nd } \\
\text { wave }\end{array}$} \\
\hline & & & & $\begin{array}{l}\text { OR } \\
(95 \% \\
\text { Cl) }\end{array}$ & $\begin{array}{l}\mathrm{P} \\
\text { value }\end{array}$ & $\begin{array}{l}\text { OR } \\
\text { (95\% } \\
\text { Cl) }\end{array}$ & $\begin{array}{l}P \\
\text { value }\end{array}$ & $\begin{array}{l}\text { OR } \\
(95 \% \\
\text { Cl) }\end{array}$ & $\begin{array}{l}P \\
\text { value }\end{array}$ \\
\hline $\begin{array}{l}\text { Gestational } \\
\text { Hypertension }\end{array}$ & $53(4.8)$ & $46(8.6)$ & $13(4.9)$ & $\begin{array}{l}1.9 \\
(1.2- \\
2.8)\end{array}$ & .001 & $\begin{array}{l}1.0 \\
(0.6- \\
1.9)\end{array}$ & .93 & $\begin{array}{l}0.6 \\
(0.3- \\
1.0)\end{array}$ & .06 \\
\hline Preeclampsia/Eclampsia & $64(5.8)$ & $36(6.7)$ & $18(6.8)$ & $\begin{array}{l}1.2 \\
(0.8- \\
1.8)\end{array}$ & .46 & $\begin{array}{l}1.2 \\
(0.7- \\
2.1)\end{array}$ & .52 & $\begin{array}{l}1.0 \\
(.6- \\
1.8)\end{array}$ & .95 \\
\hline Eclampsia & $5(0.4)$ & $2(0.4)$ & $4(1.5)$ & $\begin{array}{l}0.8 \\
(0.2- \\
4.3)\end{array}$ & $>.99$ & $\begin{array}{l}4.4 \\
(0.9- \\
12.7)\end{array}$ & .15 & $\begin{array}{l}4.1 \\
(0.8- \\
22.6)\end{array}$ & .19 \\
\hline $\begin{array}{l}\text { Hemorrhagic } \\
\text { complications* }\end{array}$ & $23(2.1)$ & $7(1.3)$ & $4(1.5)$ & $\begin{array}{l}0.6 \\
(0.3- \\
1.5)\end{array}$ & .27 & $\begin{array}{l}0.8 \\
(0.3- \\
2.1)\end{array}$ & .55 & $\begin{array}{l}1.2 \\
(0.3- \\
4.0)\end{array}$ & $>.99$ \\
\hline \multicolumn{10}{|l|}{$\begin{array}{l}\text { COVID-19 severity and } \\
\text { outcomes }\end{array}$} \\
\hline $\begin{array}{l}\text { ICU/HDU admissions ( } \mathrm{n}, \\
\%)\end{array}$ & $27(2.4)$ & $88(14.7)$ & $7^{\mathrm{b}}(2.4)$ & $\begin{array}{l}7.2 \\
(4.6- \\
11.1)\end{array}$ & $<.001$ & $\begin{array}{l}1.0 \\
(0.4- \\
2.4)\end{array}$ & .95 & $\begin{array}{l}0.1 \\
(0.1- \\
0.3)\end{array}$ & $<.001$ \\
\hline Case fatality rate & $8(0.7)$ & $38(6.4)$ & 0 & $\begin{array}{l}9.6 \\
(4.5- \\
20.8)\end{array}$ & $<.001$ & & - & - & - \\
\hline $\begin{array}{l}\text { Maternal mortality ratio } \\
\text { (per 1,000 births) }\end{array}$ & $8(9.7)$ & $38(96.7)$ & 0 & $\begin{array}{l}10.9 \\
(5.0- \\
23.5)\end{array}$ & $<.001$ & & - & - & - \\
\hline $\begin{array}{l}\text { Completely vaccinated } \\
\text { for COVID-19 }\end{array}$ & 0 & 0 & $11(3.8)$ & & & & & & \\
\hline $\begin{array}{l}\text { Partial Vaccination for } \\
\text { COVID-19 }\end{array}$ & 0 & 0 & $14(4.9)$ & & & & & & \\
\hline \multicolumn{10}{|c|}{ * Hemorrhagic complications include antepartum hemorrhage + postpartum hemorrhage + hemoperitoneum } \\
\hline \multicolumn{10}{|c|}{ a Cardiac Disease includes rheumatic heart disease + congenital heart disease + peripartum cardiomyopathy } \\
\hline \multicolumn{10}{|c|}{$\begin{array}{l}\text { b Out of } 7 \text { ICU/HDU admissions during the third wave one was moderate COVID-19, other six were not related to COVID- } \\
19 \text { severity; two were pulmonary edema secondary to severe preeclampsia/eclampsia (one had stillbirth and was on NIV, } \\
\text { other needed invasive ventilation), one was eclampsia with posterior reversible encephalopathy syndrome (PRES), one } \\
\text { was severe rheumatic mitral stenosis and two were ruptured ectopic (one with massive blood loss needing ionotropic } \\
\text { support and other had transfusion reaction). }\end{array}$} \\
\hline
\end{tabular}

Data are presented as frequency (\%) or median (IQR) and odds ratio $(95 \% \mathrm{Cl})$. Fisher's exact or Chi-square test for categorical variables and Mann-Whitney $U$ test for continuous variables were applied for analysis of different waves of COVID-19 at the significance level of $p<.05$. The statistical analysis was conducted using SPSS Statistics Base 26.0. The study was approved by the Ethics Committees of NH (ECARP\#2020-63) and ICMR-NIRRH (ICEC\#2020-404). The study is registered with the Clinical Trial Registry of India (CTRI\#2020-025423).

\section{Results}


The Mumbai Metropolitan Region in Maharashtra, India experienced three distinct waves of COVID-19 (Table 1, Figure 1). The hospitalization rate of pregnant and post-partum women with COVID-19 during the first four weeks of the third wave was higher than the earlier two waves as 288 women got admitted within the 33-day period (Figure 1). The median age of pregnant and postpartum women admitted with SARS-CoV-2 infection during the third wave was significantly lower than the first and second waves respectively ( $p=.02, p=.001)$. The number of SARS-CoV-2 infected pregnant and post-partum women with symptoms of COVID-19 were five times higher during the third wave as compared to the first wave (OR=5.1, $95 \% \mathrm{Cl}, 3.8-6.7, \mathrm{p}<.001)$. On the contrary, there was a significantly lower proportion of pregnant and postpartum women with moderate to severe COVID-19 during the third wave $(0.3 \%, 1 / 288)$ as compared to those during the first wave $(2.4 \%$, $27 / 1143, p<.001)$ and second wave $(14.4 \%, 86 / 597)$ [p<.001]. The ICU/HDU admissions during the third wave were significantly lower $(2.4 \%, 7 / 288)$ than those during the second wave $(14.7 \%, 88 / 597)[\mathrm{OR}=0.1,95 \% \mathrm{Cl}, 0.1-0.3, \mathrm{p}<.001]$ but similar to the first wave $(2.4 \%, 27 / 1143)$. No maternal deaths were reported during the third wave till 19 th January 2022.

The proportion of pregnant and postpartum women with anemia was significantly lower during the third wave (45.8\%, $132 / 288)$ as compared to the second wave $(59.6 \%, 356 / 597)$ [OR=0.6, 95\% Cl, 0.4-0.8, $\mathrm{p}<.001]$. The proportion of caesarean sections was significantly lower during the third wave as compared to the first wave $(\mathrm{OR}=0.7,95 \% \mathrm{Cl}, 0.5-0.9, p=.01)$. The spontaneous preterm birth rate (per 1000 births) was lower during the third wave (60.9) as compared to the second wave (106.9) and first wave (81.5); this difference did not reach statistical significance. The spontaneous abortion rate (per 1000 births) was higher during the third wave (45.7) as compared to the first wave (26.8) $(p=.17)$ but lower than the second wave (76.3) $(p=.16)$

The frequency of gestational diabetes mellitus (GDM) in pregnant women with SARS-CoV-2 infection was significantly lower during the third wave (1.9\%) as compared to those during the second wave (5.2\%) [OR=0.4; 95\% $\mathrm{Cl}, 0.1-0.9, \mathrm{p}=.03$ ]. Eclampsia was observed four times higher during the third wave as compared to the second wave (OR=4.1, 95\% $\mathrm{Cl}, 0.8-22.6$, $\mathrm{p}=.19)$ and first wave $(\mathrm{OR}=4.4,95 \% \mathrm{Cl}, 0.9-12.7, \mathrm{p}=.15)$. There were $3.8 \%(11 / 288)$ of pregnant women who received two doses of either Covaxin or Covishield (ChAdOx1 nCoV- 19) vaccines whereas partial vaccination was reported in $4.9 \%$ (14/288) of pregnant women admitted with COVID-19 at NH during the third wave of COVID-19.

\section{Discussion}

The third wave of the SARS-CoV-2 outbreak has spread with unparalleled speed in the Mumbai Metropolitan Region as compared to the earlier two waves. Hospital admissions increased rapidly within a period of four weeks during the third wave of COVID-19. This exhibits a different transmission curve and epidemiological profile from the previous two waves of COVID-19 in India. During the first four weeks of this new COVID-19 surge, we observed the seven major differences amongst the pregnant and post-partum women with COVID-19 compared to the earlier two waves: 1) women in the younger age group were admitted during the third wave as compared to earlier two waves of COVID-19; 2) the proportion of pregnant and postpartum women with symptomatic COVID-19 was higher; 3 ) the proportion of moderate-severe disease, ICU/HDU admissions, and maternal mortality was lower as compared to the earlier two waves; 4) spontaneous preterm birth rate per 1000 births was lower during the third wave as compared to earlier two waves; 5) spontaneous abortion rate per 1000 births was higher during the third wave as compared to the first wave but lower than the second wave; 6) GDM was lower during the third wave as compared to the second wave, and 7) eclampsia was higher during the third wave as compared to earlier two waves. An important consideration in the interpretation of these results is that these are early observations from a single center representing a population of 26 million in the Mumbai Metropolitan Region, India.

The higher proportion of symptomatic COVID-19 is likely due to immune evasion and potential intrinsic increased transmissibility of the new variant of concern, Omicron. ${ }^{8}$ The decline in the proportion of severe COVID-19 disease amongst pregnant and post-partum women during the third wave in India was similar to the general population as observed in South Africa. ${ }^{8}$ The rise in symptomatic cases during the third wave could be due to multiple factors including increasing awareness of COVID-19 symptoms and early referral to the hospitals, better preparedness of the COVID-19 hospitals with all 
specialties required to manage pregnant women with COVID-19. The decline in severity of COVID-19 may be attributed to the fact that Omicron infection causes less severe disease as compared to Delta ${ }^{10,11}$ and Omicron infection is mainly limited to the upper respiratory tract. ${ }^{12,13}$ However, more data are needed to better understand the factors responsible for a higher number of symptomatic cases and decline in severe COVID-19 cases during the third wave of COVID-19.

Although the Government of India recommended the inclusion of pregnant women in the COVID-19 vaccination schedule on 2nd July 2021, there is still hesitancy for vaccination leading to low vaccination coverage in pregnant women as only $3.8 \%$ of pregnant women with two doses of vaccination were observed during the third wave.

Limitations of the study include the single-center study and the non-availability of genome sequencing data to confirm the SARS-CoV-2 variants during three waves of the COVID-19 pandemic. To conclude, early surveillance data indicate that the third wave is associated with higher symptomatic cases, lower severity, and lower fatality among pregnant and postpartum women with COVID-19.

\section{Declarations}

\section{Acknowledgments}

The authors sincerely thank the Network of National Registry of Pregnant women with Covid-19 in India (CTRI/2020/05/025423). Faculties, Resident doctors, and Interns in the Department of Obstetrics and Gynecology at TNMC, Mumbai, are sincerely acknowledged. The authors thank Dr. Periyasamy Kuppusamy, Ph.D., and Dr. Hrishikesh Munshi, MBBS, MPH, ICMR-NIRRCH for the assistance in statistical analysis and preparation of the figure. The study is supported by an intramural grant of ICMR-NIRRCH (ICMR-NIRRCH/RA/01/1190). Dr. Rahul K Gajbhiye is an awardee of the DBT-Wellcome India alliance clinical and public health intermediate fellowship (Grant no. IA/CPHI/18/1/503933).

\section{Author contributions}

NM and RG had full access to all of the data in the study and take responsibility for the Integrity of the data and the accuracy of the data analysis. Concept and design: NM, RG. Data collection: SK, CS, PK, PY, JS, SS. Acquisition of data: SK, CS, PK, PY, JS, SS. Analysis, or interpretation of data: All authors. Drafting of the manuscript: RG and NM. Critical revision of the manuscript for important intellectual content: RG, NM, SM. Statistical analysis: NM, and RG. Administrative and technical or material support: NM, RG, GS, SM.

Funding: No external funding

\section{Declarations of conflict of interest:}

The authors have no conflicts of interest to declare.

\section{Availability of Data and Material:}

Data is available on request to the corresponding author.

\section{Ethics Approval:}

The study was approved by the Ethics Committees of TNMC (No. ECARP/2020/63 dated 27.05.2020) and ICMR-NIRRH (IEC no. D/ICEC/Sci-53/55/2020 dated 04.06.2020).

\section{Trial Registration:}

The study is registered with the Clinical Trial Registry of India (Registration no: CTRI/2020/05/025423). 


\section{References}

1. World Health Organisation. Technical document: Enhancing response to Omicron SARS-CoV-2 variant, 7 January 2022. Accessed 19th January 2022. <background-color:\#FF3300;uvertical-

align:super;>https://www.who.int/publications/m/item/enhancing-readiness-for-omicron-(b.1.1.529)-technical-briefand-priority-actions-for-member-states</background-color:\#FF3300;uvertical-align:super;><uvertical-align:super;>. $</$ uvertical-align:super;>

2. The Indian SARS-CoV-2 Genomics Consortium (INSACOG) weekly bulletin, 3rd January 2022. Accessed 24th January 2022. https://dbtindia.gov.in/sites/default/files/INSACOG-WEEKLY\%20Bulletin_03-01-2022.pdf

3. MoHFW | Home. https://www.mohfw.gov.in/. Accessed on 20th Jan 2022.

4. Gajbhiye RK, Mahajan NN, Waghmare RB, et al. Clinical characteristics, outcomes, \& mortality in pregnant women with COVID-19 in Maharashtra, India: Results from PregCovid registry. Indian J Med Res. 2021;153(5-6).

5. Mahajan NN, Pophalkar M, Patil S, et al. Pregnancy Outcomes and Maternal Complications During the Second Wave of Coronavirus Disease 2019 (COVID-19) in India. Obstet Gynecol. 2021;138(4).

6. Mahajan NN, Pednekar R, Patil SR, et al. Preparedness, administrative challenges for establishing obstetric services, and experience of delivering over 400 women at a tertiary care COVID-19 hospital in India. Int J Gynecol Obstet. 2020;151(2):188-196.

7. Gajbhiye RK, Mahajan NN, Waghmare R, et al. Protocol for a prospective, hospital-based registry of pregnant women with SARS-CoV-2 infection in India: PregCovid Registry study. medRxiv 2021.

07.21 .21260823

. doi:10.1101/2021.07.21.21260823

8. Pearson CAB, Silal SP, Li MWZ, et al. Bounding the levels of transmissibility immune evasion of the Omicron variant in South Africa. medRxiv.2021.12.19.21268038. doi:10.1101/2021.12.19.21268038

9. Abdullah F, Myers J, Basu D, et al. Decreased severity of disease during the first global omicron variant covid-19 outbreak in a large hospital in tshwane, south africa. Int J Infect Dis. 2022;116:38-42. doi:10.1016/j.jij.2021.12.357

10. Butt AA, Dargham SR, Chemaitelly H, et al. Severity of Illness in Persons Infected With the SARS-CoV-2 Delta Variant vs Beta Variant in Qatar. JAMA Intern. Med. 2021. doi:10.1001/jamainternmed.2021.7949

11. Dyer O. Covid-19: Omicron is causing more infections but fewer hospital admissions than delta, South African data show. BMJ. 2021;375:n3104.

12. Diamond M, Halfmann P, Maemura T, et al. The SARS-CoV-2 B.1.1.529 Omicron virus causes attenuated infection and disease in mice and hamsters. Preprint. Res Sq. 2021; rs.3.rs-1211792. Published 2021 Dec 29. doi:10.21203/rs.3.rs1211792/v1

13. Zhao H, Lu L, Peng Z, et al. SARS-CoV-2 Omicron variant shows less efficient replication and fusion activity when compared with Delta variant in TMPRSS2-expressed cells. Emerg Microbes Infect. 2022;11(1):277-283. doi:10.1080/22221751.2021.2023329

\section{Figures}




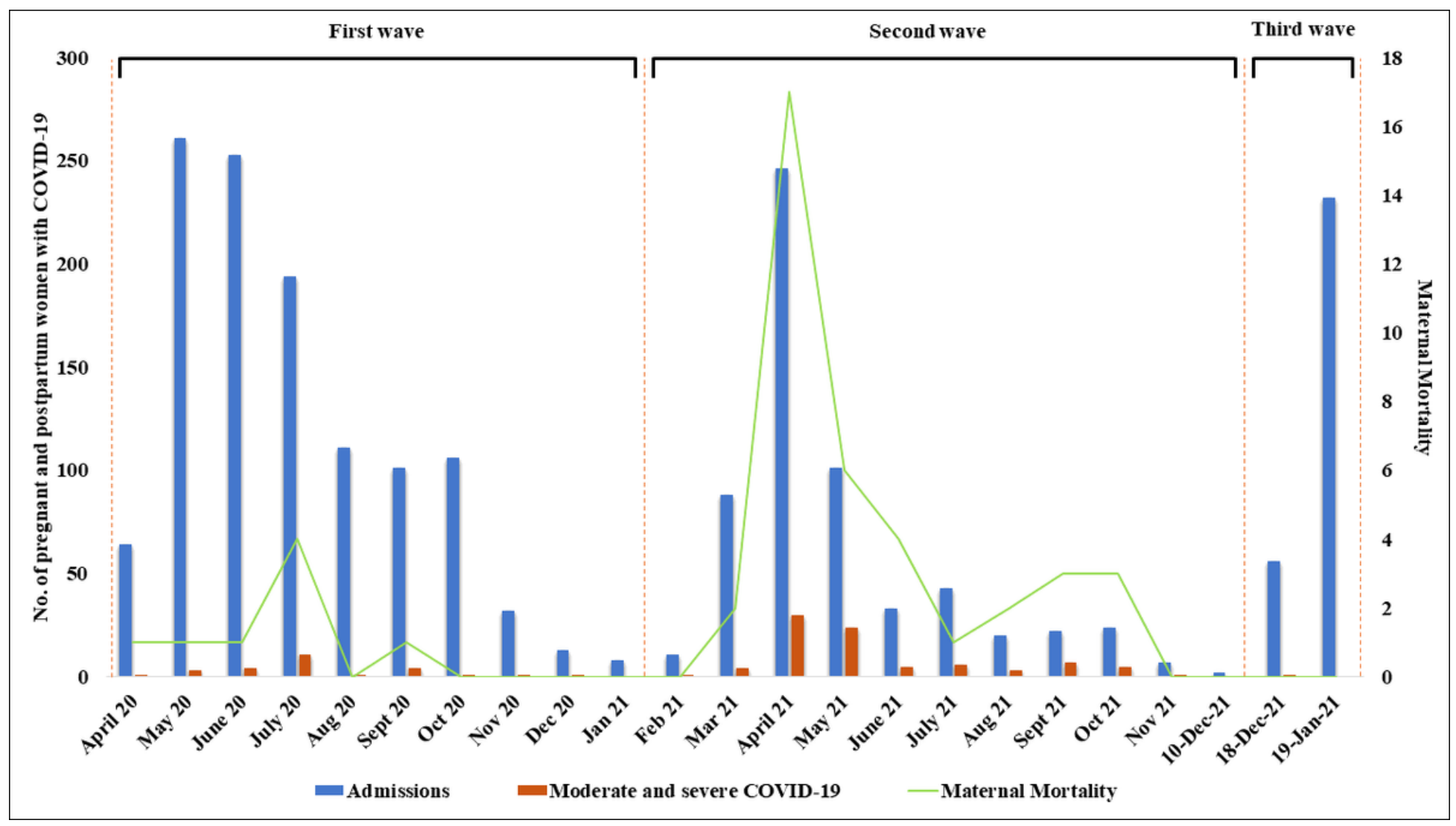

Figure 1

Timelines of the first, second, and third waves of coronavirus disease 2019 (COVID-19) in Mumbai Metropolitan Region, India. 